\title{
Autonomic Profile, Physical Activity, Body Mass Index and Academic Performance of School Students
}

\author{
Daniel Mendoza-Castejón ${ }^{1}$ and Vicente Javier Clemente-Suárez ${ }^{1,2, *(D)}$ \\ 1 Faculty of Sport Sciences, Universidad Europea de Madrid, Villaviciosa de Odón, 28670 Madrid, Spain; \\ daniel.mendoza@universidadeuropea.es \\ 2 Grupo de Investigación en Cultura, Educación y Sociedad, Universidad de la Costa, \\ Barranquilla 080002, Colombia \\ * Correspondence: vctxente@yahoo.es; Tel.: +34-902-232-350; Fax: +34-911-413-585
}

Received: 17 July 2020; Accepted: 17 August 2020; Published: 19 August 2020

check for updates

\begin{abstract}
The aim of this study was to analyze the autonomic modulation, physical activity, body mass index, and academic performance of preschool and school students by grade. Extracurricular physical activity, heart rate variability, body mass index, and objective and subjective academic performance were analyzed in 180 preschool and primary school students $(7.91 \pm 2.29$ years). Significant lower heart rate and higher parasympathetic modulation were found in 10-12-year-old primary education students. The 8-9-year-old students obtained the worst results in English and in five of the subjective academic performance items. Students aged 10-12 years old presented the highest body composition values. No significant differences were found on the extracurricular physical activity by age. No correlation between autonomic profile, physical activity, and body composition with objective academic performance was found. Nerveless subjective academic performance perception of teachers presented a negative correlation with body composition and the parasympathetic modulation. School students presented an increased body mass index and parasympathetic modulation by age. Physical activity of all students, independently of the age, were lower than the official recommendations.
\end{abstract}

Keywords: education; heart rate variability; physical exercise; body mass index

\section{Introduction}

Success in the educational process is usually related to aspects that reflect in individual qualification depending on the knowledge area, daily performance, and attitude. The assessment of these elements is usually based on solving tests, making specific works, or daily tasks to check the student's continuous progress [1,2]. However, multiple complex variables, such as individual qualities, sociocultural-economic environment, and school reality, could directly or indirectly influence the student's status and their academic performance. In this line, students' quality of life plays a key role in their academic performance [3-5].

It is known that promoting healthy habits (including physical activity) during early school age seems to be quite noteworthy to improve academic achievement [6,7] and could be capital to keep a healthy lifestyle in the future, especially in western countries with an important increase in sedentarism and obesity [8-10]. In this line, an excessive fat percentage was related to increased morbidity and mortality. Body mass index (BMI) is a basic and simple indicator to compare individual body status with standard population, but is necessary to note that one's BMI value could be associated to different body fat percentages affected by age, sex, ethnicity, or individual differences. In education, BMI has been usually associated with academic results in children and adolescents, showing a negative correlation [11,12]. High BMI values could be signs of an unhealthy lifestyle and increased internal stress in children that could affect their performance at school $[13,14]$. Physical education at school has 
structured programs aiming to reach this purpose [15]. This is important since the amount of physical activity, sport practice, kind of practice, and the intensity carried out by students in their free time are considered important factors for the students' multidimensional growth [16,17].

Previous researches pointed out several physical and physiological benefits of moderate and regular physical practice in school children [18], including brain and cognitive functioning such as perception, decision, execution, concentration, and memory $[19,20]$. All these elements could help to deal with routine academic requirements and even with specific events such as tests or exams in different areas as mathematical calculation, linguistic reasoning, or creativity [21-24]. Despite the benefits found on health, fitness, and short-term academic improvements on students, there is still no evidence on the influence of physical activity practice on long-term academic performance, requiring more studies that explain these influences [25-27]. Currently, there is a widespread trend among students and their families regarding the reduction of physical practice when the academic demand increases, or when the educational stage changes $[28,29]$. On the contrary, a recent research found that maintaining the daily routine in terms of number of sessions per week, volume and intensity of physical activity does not negatively affects grades of students on evaluation periods. In fact, students with better academic profiles were those who played more sport [30].

Another remarkable aspect is that elementary students is a sensitive population to suffer increased anxiety levels because they present a lack of self-control or fewer tools to face this kind of stressful situations, such as evaluation periods, than other educational stages such as secondary or higher education [31-33]. Previous studies conducted in higher education stage showed how the psychological profile of students is an important variable to keep stress under control [34,35], which is essential to reach a correct learning process [36]. The academic environment generates stress that can be detected by the heart rate variability (HRV) measurements [37], being a useful tool to analyze autonomic nervous system dysregulation due to the stress in early educational stages [38]. The cathartic function of physical activity is an interesting utilitarian dimension for students [39,40], reducing their sympathetic activation and stabilizing their autonomic modulation. Therefore, it could help them cope with academic stress and anxiety, improving their academic performance.

In order to improve knowledge in this multifactorial stress area, we conducted the present research with the aim to analyze the autonomic modulation, physical activity, body mass index, and academic performance of preschool and school students by grade. The initial hypothesis was that students with higher physical activity and lower body mass index would present higher parasympathetic modulation and higher academic performance.

\section{Materials and Methods}

\subsection{Participants}

We analyzed 180 Spanish preschool and primary school students $(7.91 \pm 2.29$ years, from 3 to 12 years). The division by age was made as follows: pre-school education ( $3-5$ years), $n=27$; first primary stage (6-7 years) corresponding to 1 st and 2 nd school year, $n=58$; second primary stage (8-9 years), corresponding to 3 rd and 4 th school year, $n=51$; third primary stage (10-12 years), corresponding to 5 th and 6 th school year, $n=44$. All participants, parental or guardian figures, and their professors were informed about the experimental procedures, indicating the right to withdraw from the study at any time and providing a written informed consent before starting the study, following the Helsinki Declaration (as revised in Brazil, 2013). All the data were collected anonymously, and the procedure was approved by the European University of Madrid Ethical Committee (CIPI/18/074).

\subsection{Procedure}

The present descriptive and non-experimental research based in quantitative data analyzed physiological stress markers, extracurricular physical activity, body mass index, and academic performance in school students. The data collection took place in the last week of the first term 
evaluations and before the report cards were given. To reduce possible students' anxiety at the time of measurement, the researchers visited the schools to introduce themselves to the children, presenting the devices used for the data collection. Physical education teachers helped with this propose. Furthermore, the students who participated in the study had filled out particularly a small booklet two weeks at home before the collection of HRV data at the school. Parents and teachers cooperated to help them, explaining the most difficult questions especially for the earliest ages. Previously, they were informed about the instructions and each item meaning. The document contained their basic data and the questionnaires specified below. Likewise, the center provided the students' grades with their express authorization.

The HRV analysis was conducted using the Polar V800 heart rate monitor (Polar, Kempele, Finland). The RR waves interval of the heartbeat (temporal distance in milliseconds of the consecutive $\mathrm{R}$ waves of an electrogram) were recorded consistent with previous research [41]. Following previous procedures [42,43], we analyzed the HRV for five minutes prior to start a regular school day, with the students seated in a quiet room. The R-R series was analyzed using the Kubios HRV software, version 2.0 (Biosignal Analysis and Medical Imaging Group, University of Kuopio, Finland), developed in accordance with the recommendations of the existing scientific literature [44,45]. The next HRV variables were evaluated: heart rate mean (HRmean) and the sensitivity of the short-term variability (SD1) and long-term variability (SD2) of the non-linear spectra of the HRV; percentage of differences between normal adjacent R-R intervals greater than $50 \mathrm{~ms}$ (pNN50); the square root of the average of the sum of the differences squared between normal adjacent R-R intervals (RMSSD); the low-frequency band in normalized units (low-frequency LFn); the high-frequency band in normalized units (high-frequency, HFn); and LF/HF ratio. These variables provide information on the student's autonomic nervous system.

To analyze Physical Activity profile, the validated self-report questionnaire in children and adolescents, (Physical Activity Questionnaire for Children and Adolescents) PAQ-C and PAQ-A, respectively [46,47], was employed. These questionnaires were selected due to their easy application and because they are two of the most employed questionnaires in these populations.

The Body Mass Index (BMI) was calculated using the classic formula: weight $(\mathrm{kg}) / \mathrm{height}(\mathrm{m})^{2}$, because bioimpedance and other anthropometric measurements were not available, accepting the limitation of the result. Weight and height were measured in physical education class and BMI was calculated later. BMI was used because it is a widely used standard measure for weight categories that may lead to health problems [48].

To analyze subjective perception of students' academic performance (SPAP), a questionnaire about the teachers' subjective perception of students' academic performance was filled, in which they answered the following five questions in a 1 (never) to 5 (always) rank: "Student shows interest and curiosity in learning new things?", "Student works to finish the tasks you begin?", "Student stays calm and in control when faced with a challenge?", "Student cares about doing well in school?", and "Student does all the work required?" Each teacher completed the questionnaire about their class group alone at the school.

The objective academic performance was analyzed by the academic qualification of each subject carried out by the students and the total average of all the subjects. This basic information was provided by the school direction with official data.

\subsection{Statistical Analysis}

The statistical analysis was carried out using the Statistical Package for the Social Sciences (SPSS) version 24.0 (SPSS Inc., Chicago, IL, USA). Descriptive statistics (mean and standard deviation) were calculated for each variable. The normality was tested by the Kolmogorov-Smirnov test. As all the variables presented a parametric distribution, a MANOVA with age group as fixed factor was conducted to explore differences in the variables analyzed. Finally, a bivariate correlation analysis was performed using the Pearson test. The significance level was $p \leq 0.05$. The effect size was also calculated. 


\section{Results}

The MANOVA presented significant differences between age groups (F: 6252; $p: 0.000 ; \eta^{2}: 0.894$ ). This analysis found significantly lower HR mean values in primary 3rd stage than preschool students and the others primary groups. No significant differences have been found between groups in the other HRV variables measured (Table 1).

Table 1. Heart rate variability of students.

\begin{tabular}{|c|c|c|c|c|c|c|c|c|}
\hline Variable & $\begin{array}{c}\text { Group } 1 \\
\text { Preschool }\end{array}$ & $\begin{array}{c}\text { Group } 2 \\
\text { Primary } \\
\text { 1st Stage }\end{array}$ & $\begin{array}{c}\text { Group } 3 \\
\text { Primary } \\
\text { 2nd Stage }\end{array}$ & $\begin{array}{c}\text { Group } 4 \\
\text { Primary } \\
\text { 3rd Stage }\end{array}$ & F & $p$ & $\eta^{2}$ & $\begin{array}{c}\text { Group } \\
\text { Comparison }\end{array}$ \\
\hline HRmean (b/min) & $114.65 \pm 12.62$ & $101.17 \pm 10.24$ & $107.97 \pm 17.72$ & $86.36 \pm 12.89$ & 7.95 & 0.001 & 0.168 & $4<2<3<1$ \\
\hline $\mathrm{SD} 1(\mathrm{~ms})$ & $47.01 \pm 30.94$ & $39.34 \pm 16.90$ & $47.81 \pm 24.20$ & $46.46 \pm 19.26$ & 0.18 & 0.834 & 0.005 & \\
\hline $\mathrm{SD} 2$ (ms) & $127.80 \pm 116.74$ & $99.30 \pm 40.13$ & $125.51 \pm 51.84$ & $115.94 \pm 36.19$ & 0.11 & 0.892 & 0.003 & \\
\hline pNN50 (\%) & $23.11 \pm 19.49$ & $21.95 \pm 13.30$ & $26.68 \pm 15.96$ & $32.04 \pm 13.81$ & 1.51 & 0.227 & 0.037 & \\
\hline HF (n.u.) & $31.48 \pm 20.14$ & $32.38 \pm 18.60$ & $31.28 \pm 13.34$ & $38.77 \pm 14.29$ & 1.35 & 0.265 & 0.033 & \\
\hline LF/HF ratio & $5.15 \pm 9.28$ & $11.35 \pm 45.92$ & $2.90 \pm 2.12$ & $2.02 \pm 1.38$ & 1.57 & 0.214 & 0.005 & \\
\hline
\end{tabular}

HR mean, heart rate mean; RMSSD, root-mean square differences of successive heartbeat intervals; pNN50, percentage of successive RR-interval pairs differing in more than 50 milliseconds in the entire recording divided by the total number of RR waves intervals; LF: low-frequency band; HF: high-frequency band; LF/HF Ratio; SD1, transverse axis; SD2, longitudinal axis.

Regarding academic performance, significant differences were only found in English and Religion/Social Values grades, and five of the six items in the SPAP between groups. Primary 1st stage (Group 2) showed the best results in English among the groups, but primary 2nd stage (Group 3) obtained the worst results in English, as well as in five of the six SPAP items (Table 2).

Table 2. Grades and Subjective Perception of Academic Performance (SPAP) of students.

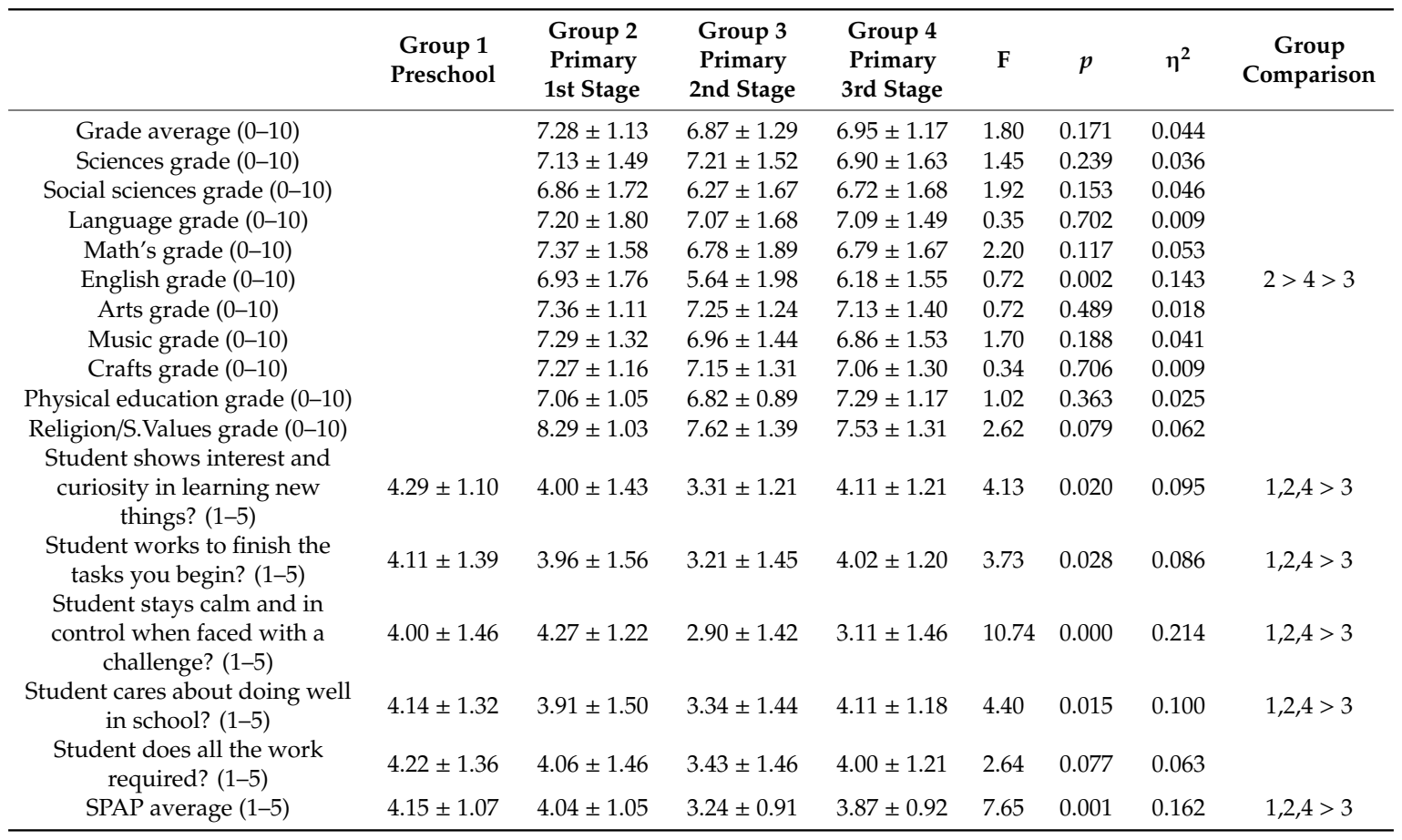

Primary 3rd stage (Group 4) presented highest values in height, weight, and BMI than younger groups (Table 3). Age seems to have a strong relation with body growth. No significant differences were found on the extracurricular physical activity by groups, but a small increased tendency with age was observed as well. 
Table 3. Body mass index and physical activity of students.

\begin{tabular}{ccccccccc}
\hline & $\begin{array}{c}\text { Group 1 } \\
\text { Preschool }\end{array}$ & $\begin{array}{c}\text { Group 2 } \\
\text { Primary } \\
\text { 1st stage }\end{array}$ & $\begin{array}{c}\text { Group 3 } \\
\text { Primary } \\
\text { 2nd stage }\end{array}$ & $\begin{array}{c}\text { Group 4 } \\
\text { Primary } \\
\text { 3rd stage }\end{array}$ & F & $p$ & $\eta^{2}$ & $\begin{array}{c}\text { Group } \\
\text { Comparison }\end{array}$ \\
\hline Height $(\mathrm{cm})$ & $108 \pm 10.20$ & $124.27 \pm 7.84$ & $138.27 \pm 8.67$ & $148.42 \pm 8.18$ & 46.00 & 0.000 & 0.538 & $1<2<3<4$ \\
Weight $(\mathrm{Kg})$ & $19.40 \pm 3.45$ & $26.92 \pm 6.18$ & $37.01 \pm 9.25$ & $43.86 \pm 10.00$ & 20.46 & 0.000 & 0.341 & $1<2<3<4$ \\
BMI $\left(\mathrm{Kg} / \mathrm{m}^{2}\right)$ & $16.82 \pm 3.41$ & $17.41 \pm 3.08$ & $19.20 \pm 3.89$ & $19.78 \pm 3.49$ & 4.38 & 0.016 & 0.100 & $1<2<3<4$ \\
PAQC-A $(1-5)$ & $1.48 \pm 0.58$ & $1.59 \pm 0.67$ & $1.61 \pm 0.58$ & $1.71 \pm 0.61$ & 0.160 & 0.852 & 0.004 & \\
\hline
\end{tabular}

BMI, Body Mass Index; PAQC-A: Physical Activity Questionnaire for Children and Adolescents.

In the correlational analysis we found a negative significant correlation between SPAP average and BMI (r: $-0.181 ; p: 0.042)$, RMSSD (r: $-0.191 ; p: 0.027)$, pNN50 (r: $-0.283 ; p: 0.001)$ and SD1 (r: $-0.191 ; p: 0.027)$.

\section{Discussion}

The aim of this study was to analyze the autonomic modulation, physical activity, body mass index, and academic performance of preschool and school students by grade. The initial hypothesis was partially confirmed since only lower body mass index correlated with better subjective academic performance.

The HRV analysis has been confirmed as a useful and non-invasive technique to measure autonomic modulation in children [49]. Students' HR mean analysis revealed a tendency to decrease by grade whereas an incremental tendency in parasympathetic modulation (RMSSD, pNN50 and SD1) was found by grade and age, coinciding with previous researches [50,51]. These results might be in accordance with a normal maturation of autonomic nervous system where parasympathetic activation increases from birth to young adulthood [52,53]. These results were in line with a normalized growth, according with the significant increase in height, weight, and BMI [54]. Previous studies have positively related higher BMI with an increase in internal physiological stress of subjects [55]. A body composition imbalance might indicate unhealthy lifestyle habits contributing to acquire non-recommended stress status [56-58].

No correlation was found between physical activity and academic performance by grade, although the amount of weekly extracurricular physical activity showed an increased tendency by grade. Some studies from the beginning of the 21st century did not conclusively find that physical activity and physical education contribute to achieve better academic results, but none of them found that these results were worsened by the practice [59]. However, current evidences indicate a positive influence on cognitive development, executive functions, specific brain areas, and some improvements on curricular areas, such as language, foreign language, mathematics, or in academic skills, as reading or arithmetic [60-63]. Independently, the values of physical activity presented in the sample analyzed were lower than the recommendations from health promoting institutions for children [64]. This circumstance brings a serious problem in western societies: the sedentary lifestyle. This habit is increasingly established among the population and it might lead to overweight and obesity as a trigger to other more severe pathologies [65]. Currently identified as one of the main problems is the time spent in front of the screens, whether for study/work needs or for new leisure modalities. Spanish children and adolescents do not follow the recommendations regarding the maximum of screen viewing [66], which is two hours per day. Thus, global interventions in children and adolescents are crucial for acquiring the right knowledge, convictions, skills, and attitudes that help shape a pro-healthy lifestyle [67].

Regarding academic performance, there were no differences in the grade average between the groups analyzed, but a slight decreasing trend from the first to the last year was found. These results could be motivated by the progressive demand and complexity of the curriculum of each school year, which requires more effort from the students. However, it would also be necessary to keep in mind other factors such as the lack of motivation and boredom that students suffer in their course's 
progression [68]. The lack of adaptation to the changes that the schools make each academic stage, limited emotional control [69], or low intrinsic motivation to engage might also be related to a poor enjoyment of their cognitive efforts [70]. Nevertheless, SPAP analysis revealed significant differences between groups in five of the six items evaluated. Daily academic performance and regular work in the classroom were better in preschool and primary 3rd stage (younger students obtained higher scores). Central ages obtained the lowest ratings, specifically in primary 2nd stage (8-9 years) with the worst score perceived. The concepts included in this evaluation are related to attitudinal aspects such as good behavior, self-control, responsibility or involvement, and proactivity in the classroom, which are frequently considered as a source of better subsequent results. Besides the specific conformation of each class group, it is not clear why these results appear in these age groups. Future research should explain this fact.

In the correlation analysis a negative correlation was found between BMI and the SPAP average, in line with previous studies where higher BMI correlated with worse academic achievements [71,72]. SPAP average also negatively correlated with RMSSD, pNN50, and SD1, variables related with a parasympathetic modulation. These results were opposite to the initial hypothesis, showing the influence of autonomous modulation in academic performance of students, but future studies with a larger sample must delve in this line for better knowledge of this complex relation. An appropriate autonomic nervous system regulation promotes a healthier general state, that, joining a higher emotional control, better self-efficacy conception and self-confidence, would prepare students for the incoming academic challenges [73,74]. These tools are basic to develop stress control abilities, reducing anxiety states in high academic demand moments, and strengthening student's self-knowledge. In this line, active exercise, playful-sporting, respiratory or emotional control have shown their effectivity to reduce stress in children [75]. Some studies have indicated that active programs in two basic dimensions of action (curricular and extracurricular), could improve the basic conditions to face daily school demands. In this line, the authors suggest an increase in the physical activity (even prior to the school day) and physical education time with higher intensity of practice, standing the teachers as a promoters for instilling a love for being active within their leisure time because physical activity practice has been recognized as a good way to provide a global development in children and adolescents [76-78]. Educational institutions should follow global guidelines and consider all those advantages and virtues to maintain health and an appropriate fitness status in school ages [79]. The entire educational community (authorities, schools, educators, students, and families) should be involved to promote positive behaviors and decrease anxiety in the school environment.

The main limitation of the present study was the small sample size. It was difficult to recruit students to conduct the complete research requirements, especially in early ages. Another limitation was the use of BMI and no use of anthropometric measurements such as skin folds and circumferences or Bioimpedance, but material limitation precluded their use. A third limitation was the absence of analysis of maturation of students, and future research might seek to address these issues.

For future research it would be interesting to explain deeply the type of physical activity and intensity of students in their leisure time. Future studies involving other higher educational stages might provide more information about the evolution of autonomic modulation, academic performance, and physical activity in students.

\section{Conclusions}

School students presented an increased body mass index and parasympathetic modulation by age. Physical activity of all students, independently of the age, were lower than the official recommendations. No correlation between autonomic profile, physical activity, and body composition with objective academic performance was found. Nerveless subjective academic performance perception of teachers presented a negative correlation with body composition and parasympathetic modulation of students. 
Author Contributions: Conceptualization, D.M.-C. and V.J.C.-S.; methodology and formal analysis, D.M.-C. and V.J.C.-S.; investigation, D.M.-C. and V.J.C.-S.; data curation, V.J.C.-S.; writing-Original draft preparation, D.M.-C.; writing-Review and editing, D.M.-C. and V.J.C.-S.; visualization, D.M.-C. and V.J.C.-S.; supervision and funding acquisition, V.J.C.-S. All authors have read and agreed to the published version of the manuscript.

Funding: This work was supported by the David A. Wilson Award for Excellence in Teaching and Learning Research Award 2017, project number XOTRIO1712.

Acknowledgments: We want to acknowledge the collaboration of students, families, and teachers.

Conflicts of Interest: The authors declare no conflict of interest.

\section{References}

1. Faragher, S. Understanding Assesment in Primary Education, 2nd ed.; SAGE Publications, Inc.: London, UK, 2014.

2. Briggs, M.; Woodfield, A.; Swatton, P.; Martin, C. Assessment for Learning and Teaching in Primary Schools, 2nd ed.; SAGE Publications, Inc.: London, UK, 2008.

3. Farooq, M.; Chaudhry, A.H.; Shafiq, M.; Berhanu, G. Factors affecting students' quality of academic performance: A case of secondary school level. J. Qual. Technol. Manag. 2011, 7, 1-14.

4. Fernández-Alonso, R.; Álvarez-Díaz, M.; Woitschach, P.; Suárez-Álvarez, J.; Cuesta, M. Implicación familiar y rendimiento académico: Menos control y más comunicación. Psicothema 2017, 29, 453-461. [PubMed]

5. Dumuid, D.; Olds, T.; Martín-Fernández, J.A.; Lewis, L.K.; Cassidy, L.; Maher, C. Academic Performance and Lifestyle Behaviors in Australian School Children: A Cluster Analysis. Health Educ. Behav. 2017, 44, 918-927. [CrossRef] [PubMed]

6. Syväoja, H.J.; Kankaanpää, A.; Kallio, J.; Hakonen, H.; Kulmala, J.S.; Hillman, C.H.; Pesonen, A.; Tammelin, T. The Relation of Physical Activity, Sedentary Behaviors and Academic Achievement Are Mediated by Fitness and Bedtime. J. Phys. Act. Health 2018, 15, 135-143. [CrossRef] [PubMed]

7. Geierstanger, S.; Amaral, G.; Mansour, M.; Walters, S. School-Based Health Centers and Academic Performance: Research, Challenges, and Recommendations. J. Sch. Health 2004, 74, 347-352. [CrossRef] [PubMed]

8. Viñas, B.R.; Majem, L.S.; Barba, L.R.; Pérez-Rodrigo, C.; Bartrina, J.A. Actividad física en la población infantil y juvenil española en el tiempo libre. Estudio enKid (1998-2000). Apunt. Med. Esport 2006, 41, 86-94.

9. Landry, B.W.; Driscoll, S.W. Physical activity in children and adolescents. PM R 2012, 4, 826-832. [CrossRef]

10. Baptista, F.; Santos, D.A.; Silva, A.M.; Mota, J.; Santos, R.; Vale, S.; Ferreira, J.P.; Raimundo, A.M.; Moreira, H.; Sardinha, L.B. Prevalence of the portuguese population attaining sufficient physical activity. Med. Sci. Sports Exerc. 2012, 44, 466-473. [CrossRef]

11. Rajagopal, M.; Briggs, A.; Omar, H. Association between School Performance and Body Mass Index. Int. J. Child Adolesc. Health 2017, 10, 59-62.

12. Alhusaini, A.A.; Buragadda, S.; Melam, G.R. Associations among body mass index, sedentary behavior, physical activity, and academic performance in school children. J. Sports Med. Phys. Fit. 2020. [CrossRef]

13. Messerli-Bürgy, N.; Arhab, A.; Stülb, K.; Kakebeeke, T.H.; Zysset, A.E.; Leeger-Aschmann, C.S.; Schmutz, E.A.; Ehlert, U.; Kriemler, S.; Jenni, O.G.; et al. Physiological stress measures in preschool children and their relationship with body composition and behavioral problems. Dev. Psychobiol. 2018, 60, 1009-1022.

14. Cedillo, Y.E.; Murillo, A.L.; Fernández, J.R. The association between allostatic load and anthropometric measurements among a multiethnic cohort of children. Pediatr. Obes. 2019, 14, e12501. [CrossRef] [PubMed]

15. Käll, L.; Malmgren, H.; Olsson, E.; Linden, T. Effects of a Curricular Physical Activity Intervention on Children's School Effects of a Curricular Physical Activity Intervention on Children's School. J. Sch. Health 2015, 85, 704-713. [CrossRef] [PubMed]

16. Berk, L.E.; del Río, M.P. Desarrollo del Niño y el Adolescente; Prentice Hall: Madrid, Spain, 2001; ISBN 8483220482.

17. Kern, M.L.; Waters, L.E.; Adler, A.; White, M.A. A multidimensional approach to measuring well-being in students: Application of the PERMA framework. J. Posit. Psychol. 2015, 10, 262-271. [CrossRef] [PubMed]

18. Loprinzi, P.D.; Cardinal, B.J.; Loprinzi, K.L.; Lee, H. Benefits and environmental determinants of physical activity in children and adolescents. Obes. Facts 2012, 5, 597-610. [CrossRef] [PubMed] 
19. Donnelly, J.E.; Hillman, C.H.; Castelli, D.; Etnier, J.L.; Lee, S.; Tomporowski, P.; Lambourne, K.; Szabo-Reed, A.N. Physical activity, fitness, cognitive function, and academic achievement in children: A systematic review. Med. Sci. Sports Exerc. 2016, 48, 1197-1222. [CrossRef]

20. Da Silva, S.G.; Arida, R.M. Physical activity and brain development. Expert Rev. Neurother. 2015, 15, 1041-1051. [CrossRef]

21. Taras, H. Physical activity and student performance at school. J. Sch. Health 2005, 75, 214-218. [CrossRef]

22. Haapala, E. Physical Activity, Academic Performance and Cognition in Children and Adolescents. A Systematic Review. Balt. J. Health Phys. Act. 2012, 4, 53-61. [CrossRef]

23. Mezcua-Hidalgo, A.; Ruiz-Ariza, A.; Ferreira, V.A.; De Loureiro, B.; Martínez-López, E.J. Physical capacities and their relation with memory, mathematical calculation, linguistic reasoning, and creativity in adolesc. Retos 2020, 2041, 473-479.

24. Alvarez-Bueno, C.; Pesce, C.; Cavero-Redondo, I.; Sanchez-Lopez, M.; Garrido-Miguel, M.; Martinez-Vizcaino, V. Academic achievement and physical activity: A meta-analysis. Pediatrics 2017, 140, e20171498. [CrossRef] [PubMed]

25. Dwyer, T.; Sallis, J.; Blizzard, L.; Lazarus, R.; Dean, K. Relation of Academic Performance to Physical Activity and Fitness in Children. Pediatr. Exerc. Sci. 2001, 13, 225-237. [CrossRef]

26. Howie, E.K.; Pate, R.R. Physical activity and academic achievement in children: A historical perspective. J. Sport Health Sci. 2012, 1, 160-169. [CrossRef]

27. Valach, P.; Vašíčková, J.; Frömel, K.; Jakubec, L.; Chmelík, F.; Svozil, Z. Is academic achievement reflected in the level of physical activity among adolescents? J. Phys. Educ. Sport 2020, 20, 186-195.

28. Brooke, H.L.; Corder, K.; Atkin, A.J.; van Sluijs, E.M.F. A Systematic Literature Review with Meta-Analyses of Within- and Between-Day Differences in Objectively Measured Physical Activity in School-Aged Children. Sports Med. 2014, 44, 1427-1438. [CrossRef] [PubMed]

29. Gordon-Larsen, P.; Nelson, M.; Popkin, B. Longitudinal Physical Activity and Sedentary Behavior Trends Adolescence to Adulthood. Am. J. Prev. Med. 2004, 27, 277-283. [CrossRef] [PubMed]

30. Clough, P. The potential benefits and costs of participation in school sport: An extended cross sectional study. Phys. Educ. Matters 2019, 3, 26-28.

31. Oberle, E.; Schonert-Reichl, K.A. Stress contagion in the classroom? The link between classroom teacher burnout and morning cortisol in elementary school students. Soc. Sci. Med. 2016, 159, 30-37. [CrossRef]

32. Kantomaa, M.T.; Stamatakis, E.; Kankaanpää, A.; Kaakinen, M.; Rodriguez, A.; Taanila, A.; Ahonen, T.; Järvelin, M.R.; Tammelin, T. Physical activity and obesity mediate the association between childhood motor function and adolescents' academic achievement. Proc. Natl. Acad. Sci. USA 2013, 110, 1917-1922. [CrossRef]

33. Sánchez-Conde, P.; Beltrán-Velasco, A.I.; Clemente-Suárez, V.J. Influence of psychological profile in autonomic response of nursing students in their first hospital clinical stays. Physiol. Behav. 2019, 207, 99-103. [CrossRef]

34. Beltrán-Velasco, A.I.; Bellido-Esteban, A.; Ruisoto-Palomera, P.; Clemente-Suárez, V.J. Use of Portable Digital Devices to Analyze Autonomic Stress Response in Psychology Objective Structured Clinical Examination. J. Med. Syst. 2018, 42, 35.

35. Beltrán, A.; Ruisoto, P.; Bellido, A.; García, M.; Clementez, V. Analysis of Psychophysiological Stress Response in Higher Education Students Undergoing Clinical Practice Evaluation. J. Med. Syst. 2019, 43, 1-7.

36. Clemente-Suárez, V.J.; Beltrán-Velasco, A.I.; Bellido-Esteban, A.; Ruisoto-Palomera, P. Autonomic Adaption to Clinical Simulation in Psychology Students: Teaching Applications. Appl. Psychophysiol. Biofeedback 2018, 43, 239-245. [CrossRef] [PubMed]

37. Mendoza-Castejon, D.; Fraile-García, J.; Diaz-Manzano, M.; Fuentes-Garcia, J.P.; Clemente-Suárez, V.J. Differences in the autonomic nervous system stress status of urban and rural school teachers. Physiol. Behav. 2020, 222, 112925. [CrossRef]

38. Mendoza-Castejón, D.; Clemente-Suárez, V.J. Psychophysiological stress markers and behavioural differences between rural and city primary school students. Int. J. Environ. Res. Public Health 2020, 17, 3157.

39. Motta, R.W.; McWilliams, M.E.; Schwartz, J.T.; Cavera, R.S. The Role of Exercise in Reducing Childhood and Adolescent PTSD, Anxiety, and Depression. J. Appl. Sch. Psychol. 2012, 28, 224-238. [CrossRef]

40. McCloy, E. The contribution of play and sports to emotional health. In Psycological Aspects of Physical Education and Sports; Kane, J.E., Ed.; Routledge: New York, NY, USA, 2016; pp. 163-186. 
41. Clemente-Suárez, V.J.; Fernandes, R.J.; Arroyo-Toledo, J.J.; Figueiredo, P.; González-Ravé, J.M.; Vilas-Boas, J.P. Autonomic adaptation after traditional and reverse swimming training periodizations. Acta Physiol. Hung. 2015, 102, 105-113. [CrossRef]

42. Shaffer, F.; Ginsberg, J.P. An Overview of Heart Rate Variability Metrics and Norms. Front. Public Health 2017, 5, 258. [CrossRef]

43. Georgiou, K.; Larentzakis, A.V.; Khamis, N.N.; Alsuhaibani, G.I.; Alaska, Y.A.; Giallafos, E.J. Can Wearable Devices Accurately Measure Heart Rate Variability? A Systematic Review. Folia Med. 2018, 60, 7-20. [CrossRef]

44. Delgado, R.; Robles-Pérez, J.; Aznar, S.; Clemente-Suárez, V. Inalambric Biofeedback Devices to Analyze Strength Manifestation in Military Population. J. Med. Syst. 2018, 42, 60. [CrossRef]

45. Clemente-Suárez, V.J.; Robles-Pérez, J.J.; Montañez-Toledo, P. Respuesta psicofisiológica en un salto táctico paracaidista a gran altitud. A propósito de un caso. Arch. Med. Deporte 2015, 32, 144-148.

46. Janz, K.; Lutuchy, E.; Wenthe, P.; Levy, S. Measuring Activity in Children and Adolescents Using Self-Report: PAQ-C and PAQ-A. Med. Sci. Sports Exerc. 2008, 40, 767-772. [CrossRef] [PubMed]

47. Kowalski, K.; Crocker, P.; Donen, R.; Honours, B. The Physical Activity Questionnaire for Older Children (PAQ-C) and Adolescents (PAQ-A) Manual; College of Kinesiology, University of Saskatchewan: Saskatoon, SK, Canada, 2004.

48. Borga, M.; West, J.; Bell, J.D.; Harvey, N.C.; Romu, T.; Heymsfield, S.B.; Leinhard, O.D. Advanced body composition assessment: From body mass index to body composition profiling. J. Investig. Med. 2018, 66, 887-895. [CrossRef]

49. Bell, C. Cardiovascular Physiology in Exercise and Sport; Elsevier Health Sciences: Amsterdam, The Netherlands, 2008; ISBN 9781455725120.

50. Perkiömäki, N.; Auvinen, J.; Tulppo, M.P.; Ollila, M.-M.; Junttila, J.; Perkiömäki, J.; Karhunen, V.; Puukka, K.; Järvelin, M.-R.; Huikuri, H.V.; et al. Childhood growth patterns and cardiovascular autonomic modulation in midlife: Northern Finland 1966 Birth Cohort Study. Int. J. Obes. 2019, 43, 2264-2272. [CrossRef]

51. Rekawek, J.; Miszczak-Knecht, M.; Kawalec, W.; Mielniczuk, J. Heart rate variability in healthy children. Folia Cardiol. 2003, 10, 203-211.

52. Plaza-Florido, A.; Migueles, J.H.; Mora-Gonzalez, J.; Molina-Garcia, P.; Rodriguez-Ayllon, M.; Cadenas-Sanchez, C.; Esteban-Cornejo, I.; Navarrete, S.; Lozano, R.M.; Michels, N.; et al. The role of heart rate on the associations between body composition and heart rate variability in children with overweight/Obesity: The active brains project. Front. Physiol. 2019, 10, 895. [CrossRef] [PubMed]

53. Silvetti, M.S.; Drago, F.; Ragonese, P. Heart rate variability in healthy children and adolescents is partially related to age and gender. Int. J. Cardiol. 2001, 81, 169-174. [CrossRef]

54. De Godoy, M.F.; Lima, M. Evolution of Parasympathetic Modulation throughout the Life Cycle. In Autonomic Nervous System Monitoring; Aslanidis, T., Ed.; IntechOpen: London, UK, 2019; ISBN 978-1-83880-519-7.

55. Goto, M.; Nagashima, M.; Baba, R.; Nagano, Y.; Yokota, M.; Nishibata, K.; Tsuji, A. Analysis of heart rate variability demonstrates effects of development on vagal modulation of heart rate in healthy children. $J$. Pediatr. 1997, 130, 725-729. [CrossRef]

56. Herzig, D.; Eser, P.; Radtke, T.; Wenger, A.; Rusterholz, T.; Wilhelm, M.; Achermann, P.; Arhab, A.; Jenni, O.G.; Kakebeeke, T.H.; et al. Relation of heart rate and its variability during sleep with age, physical activity, and body composition in young children. Front. Physiol. 2017, 8, 109. [CrossRef]

57. Sánchez, G.F.L.; Sánchez, L.L.; Suárez, A.D. Composición corporal y variabilidad de la frecuencia cardiaca: Relaciones con edad, sexo, obesidad y actividad física. Sport TK Rev. EuroAm. Cienc. Deporte 2015, 4, 33-40. [CrossRef]

58. Blom, E.H.; Olsson, E.M.G.; Serlachius, E.; Ericson, M.; Ingvar, M. Heart rate variability is related to self-reported physical activity in a healthy adolescent population. Eur. J. Appl. Physiol. 2009, 106, 877-883. [CrossRef] [PubMed]

59. Keeley, T.; Fox, K. The impact of physical activity and fitness on academic achievement and cognitive performance in children. Int. Rev. Sport Exerc. Psychol. 2009, 2, 198-214. [CrossRef]

60. Álvarez-Bueno, C.; Pesce, C.; Cavero-Redondo, I.; Sánchez-López, M.; Martínez-Hortelano, J.A.; Martínez-Vizcaíno, V. The Effect of Physical Activity Interventions on Children's Cognition and Metacognition: A Systematic Review and Meta-Analysis. J. Am. Acad. Child Adolesc. Psychiatry 2017, 56, 729-738. [CrossRef] [PubMed] 
61. Haapala, E.A.; Väistö, J.; Lintu, N.; Westgate, K.; Ekelund, U.; Poikkeus, A.M.; Brage, S.; Lakka, T.A. Physical activity and sedentary time in relation to academic achievement in children. J. Sci. Med. Sport 2017, 20, 583-589. [CrossRef]

62. Beltrán-Velasco, A.I.; Mendoza-Castejón, D.; Fuentes-García, J.P.; Clemente-Suárez, V.J. Behavioural, psychological, and physiological stress markers and academic performance in immigrant and non-immigrant preschool and school students. Physiol. Behav. 2020, 225, 113081.

63. Zeng, N.; Ayyub, M.; Sun, H.; Wen, X.; Xiang, P.; Gao, Z. Effects of Physical Activity on Motor Skills and Cognitive Development in Early Childhood: A Systematic Review. Biomed. Res. Int. 2017, 2017, 2760716. [CrossRef]

64. Wu, X.Y.; Han, L.H.; Zhang, J.H.; Luo, S.; Hu, J.W.; Sun, K. The influence of physical activity, sedentary behavior on health-related quality of life among the general population of children and adolescents: A systematic review. PLoS ONE 2017, 12, e0187668. [CrossRef]

65. Hildebrand, M.; Hansen, B.H.; van Hees, V.T.; Ekelund, U. Evaluation of raw acceleration sedentary thresholds in children and adults. Scand. J. Med. Sci. Sports 2017, 27, 1814-1823. [CrossRef]

66. Mielgo-Ayuso, J.; Aparicio-Ugarriza, R.; Castillo, A.; Ruiz, E.; Avila, J.M.; Aranceta-Bartrina, J.; Gil, A.; Ortega, R.M.; Serra-Majem, L.; Varela-Moreiras, G.; et al. Sedentary behavior among Spanish children and adolescents: Findings from the ANIBES study. BMC Public Health 2017, 17, 94. [CrossRef]

67. Wojtyła-Buciora, P.; Stawińska-Witoszyńska, B.; Wojtyła, K.; Klimberg, A.; Wojtyła, C.; Wojtyła, A.; Samolczyk-Wanyura, D.; Marcinkowski, J.T. Assessing physical activity and sedentary lifestyle behaviours for children and adolescents living in a district of Poland. What are the key determinants for improving health? Ann. Agric. Environ. Med. 2014, 21, 606-612. [CrossRef]

68. Vierhaus, M.; Lohaus, A.; Wild, E. The development of achievement emotions and coping/emotion regulation from primary to secondary school. Learn. Instr. 2016, 42, 12-21. [CrossRef]

69. Sánchez-Pérez, N.; Fuentes, L.J.; Eisenberg, N.; González-Salinas, C. Effortful control is associated with children's school functioning via learning-related behaviors. Learn. Individ. Differ. 2018, 63, 78-88. [CrossRef]

70. Luong, C.; Strobel, A.; Wollschläger, R.; Greiff, S.; Vainikainen, M.-P.; Preckel, F. Need for cognition in children and adolescents: Behavioral correlates and relations to academic achievement and potential. Learn. Individ. Differ. 2017, 53, 103-113. [CrossRef]

71. He, J.; Chen, X.; Fan, X.; Cai, Z.; Huang, F. Is there a relationship between body mass index and academic achievement? A meta-analysis. Public Health 2019, 167, 111-124. [CrossRef] [PubMed]

72. González, M.J.; Díaz-Giráldez, F.; Martín, I.; Delgado, M.; Trianes, M.V. Estrés Cotidiano Y Precisión Lectora En Niños De Educación Primaria. Int. J. Dev. Educ. Psychol. Rev. INFAD Psicol. 2016, 3, 245. [CrossRef]

73. Semple, R.J.; Droutman, V.; Reid, B.A. Mindfulness goes to school: Things learned (so far) from research and real-world experiences. Psychol. Sch. 2017, 54, 29-52. [CrossRef]

74. Aritzeta, A.; Soroa, G.; Balluerka, N.; Muela, A.; Gorostiaga, A.; Aliri, J. Reducing Anxiety and Improving Academic Performance Through a Biofeedback Relaxation Training Program. Appl. Psychophysiol. Biofeedback 2017, 42, 193-202. [CrossRef]

75. Bougea, A.; Spantideas, N.; Chrousos, G.P. Stress management for headaches in children and adolescents: A review and practical recommendations for health promotion programs and well-being. J. Child Health Care 2018, 22, 19-33. [CrossRef]

76. Ardoy, D.N.; Fernández-Rodríguez, J.M.; Jiménez-Pavón, D.; Castillo, R.; Ruiz, J.R.; Ortega, F.B. A Physical Education trial improves adolescents' cognitive performance and academic achievement: The EDUFIT study. Scand. J. Med. Sci. Sports 2014, 24, 52-61. [CrossRef]

77. Lu, C.; Montague, B. Move to Learn, Learn to Move: Prioritizing Physical Activity in Early Childhood Education Programming. Early Child. Educ. J. 2016, 44, 409-417. [CrossRef]

78. Phillips, K.L. A Zero-Hour Physical Activity Program's Benefit on Academic Achievement in Elementary Aged School Children. Ph.D. Thesis, Middle Tennessee State University, Murfreesboro, TN, USA, 2017.

79. World Health Organization. Global Action Plan on Physical Activity 2018-2030: More Active People for a Healthier World; World Health Organization: Geneva, Switzerland, 2018.

(C) 2020 by the authors. Licensee MDPI, Basel, Switzerland. This article is an open access article distributed under the terms and conditions of the Creative Commons Attribution (CC BY) license (http://creativecommons.org/licenses/by/4.0/). 